\title{
Visualizing Excursion Tours as a Way to Increase the Public Image Attractiveness of the Region (By the Example of Smolensk Region)
}

\author{
Aleksandr Volodchenkov \\ Humanities and Sciences Dep. \\ Smolensk Branch of Plekhanov Russian University of \\ Economics \\ Smolensk, Russia \\ alexmw2012@yandex.ru \\ Svetlana Shcherbakova \\ Managements and Customs Dep. \\ Smolensk Branch of Plekhanov Russian University of \\ Economics \\ Smolensk, Russia \\ sollos@mail.ru \\ Konstantin Kupchenko \\ Humanities and Sciences Dep. \\ Smolensk Branch of Plekhanov Russian University of \\ Economics \\ Jurisprudence Dep. \\ Smolensk Branch of The Russian Presidential Academy Of \\ National Economy And Public Administration \\ State and legal disciplines Dep. \\ Smolensk Branch of the Saratov state Academy of law \\ Smolensk, Russia \\ konstan1977@yandex.ru
}

\author{
Lyudmila Zhebrunova \\ Humanities and Sciences Dep. \\ Smolensk Branch of Plekhanov Russian University of \\ Economics \\ Smolensk, Russia \\ ludmila.888@mail.ru

\section{Valery Mel'nikov} \\ Managements and Customs Dep. \\ Smolensk Branch of Plekhanov Russian University of \\ Economics \\ Smolensk, Russia \\ kaf_egd@mail.ru
}

\author{
Olesya Kirsanova \\ Management and natural Sciences Dep. \\ Smolensk Academy of Phisical Culture, Sport and Tourism \\ Smolensk, Russia \\ larsuna@mail.ru
}

\begin{abstract}
The article presents the results of the research aimed at revealing theoretical and methodological backgrounds of how to improve the brand image of Smolensk region. The investigated issue is all the more acute as Smolensk region is a strategically important Russian region adjacent both to the border and to the capital.

The study defines the factors that might contribute to shaping the up-to-date region's image through the introduction of the new technologies (visualizing of the excursion tours via augmented VR) into the development of tourism as a prospective direction of the region's economy.

The above-mentioned innovative technologies to actualize the characteristics making up a favorable regional brand will certainly contribute to the stable development of tourism and the region's investment attractiveness.
\end{abstract}

Keywords: border region, region's competitiveness, regional (brand) image, tourist activity, visualization

\section{INTRODUCTION}

To strengthen the competitiveness both on the domestic and foreign markets, the region as any economic entity must have a favorable public image that will facilitate building the foundations and reinforcement of the competitive advantages of particular branches of economy and of the territorial entity (region) as a whole.

In order to strengthen the competitive status and subsequently to increase the investment attractiveness of the region it is the most efficient in our opinion to build objective vision of the region's contemporary image as the first impression will predetermine the following success 
been paid enough attention to due to the technical complexities[32, 33, 34, 35, 36? 37]. Researchers have not yet addressed the topic of the tour visualization in terms of increasing the brand-image attractiveness of the region as well. s of which are represented by this article, lies aggravation of competition among Russia's regions for the access to the financial, investment and social resources. It is against this background that the image component in the entity's strategic development is acquiring more significance and is becoming an efficient instrument of the regional positioning and providing competitive advantages.

Smolensk region is one of the main regions allowing access of the Russian Federation to near and far abroad. Therefore it is vitally important for the region to search new ways for long-term development and growth that is deemed possible by means of building highly competitive investment attractiveness.

When there is fierce competition for resources and markets, regions must offer their own resources to every potential investor, business partner or government agency resources tending to sustainable development: prospective targets in the region's economy, product trademarks (brands) contributing to and characterizing a regional brand image. One of the instruments of shaping the investment attractiveness and competitiveness is place branding assuring the development of socio-economic sphere of the region, effective implementation of the tactics and strategy of the region's place marketing, also promoting the thematic regional brand and supplementing the positive image of the tourist destination[1].

\section{Methodology}

The issues connected with the improvement of a region's brand image have been studied in the context of creating a steady favorable investment climate by the example of certain regions $[2,3,4,5,6,7,8,9,10,11,12,13,14,15,16,17,18]$ including Smolensk region and of certain industries, including tourism[19, 20, 21, 22, 23, 24, 25, 26, 27, 28, 29].

Smolensk region is a unique Russian region that is simultaneously 'near capital' and 'near border'. Due to its beneficial environmental situation, aesthetic attractiveness of the landscape, character of the atmosphere circulation, density of the cultural heritage sites and geographic and transport routes, Smolensk region is able to turn into the area of mass tourism and recreation for the capital region, other leading agglomerations and industrial centers of Russia. [30, 31].

Innovations appear one of the factors of the region's economic growth playing an important role in increasing competitiveness and shaping a well-established investment climate. At the same time innovations have become one of the urgent issues of today's market. These processes are closely connected with the product diversity and customers' dubious attitude to the new developments and novelties therefore it is a vitally important though complicated task for the innovational marketing to create both offer of and demand for the innovative brand-new products, services and technologies.

At present one of the most advanced and high-demand technologies in the tourist industry is a visualization technique via augmented virtual reality. Still in Russia this issue has not

\section{RESULTS}

The place brand image reflects the modern state of economy, politics, population, geography and climate, peculiar features of history, religion and culture, people's mentality, science and education, sport, etc., the level of territorial development on the whole. The destination's image shaping is going on under the influence of different subjective and objective factors which designate the preferences on the market. Success of the regional image foremost depends on a well-balanced correlation of the regional image being cultivated with the objective characteristics of the entity (region) on the one hand and the customer's expectations and requirements on the other.

As for today Smolensk region is at the very beginning of this process - the process of cultivating a positively viewed place brand image therefore it is necessary to include the region's every strength. Having all the premises for developing and increasing competitiveness and investment attractiveness, a high natural-resources potential, a vast accumulated cultural and historic capital, an advantageous geographic position, the region has been however for a long period of time demonstrating an insufficient level of the investment attractiveness and consequently, competitiveness. We believe that formation of the complex development programs for Smolensk region represents one of the prospective directions to build up the favorable brand image[30, 31, 38, 39, 40].

One of the major drivers of the place development is tourism. The effective development of tourism in Smolensk region is connected with well-balanced establishing and functioning of the tourist cluster here together with a wise implementation of the border placement advantages. Therefore at the beginning of 2017 there was made a decision to form a "Tourist Cluster" and "The Strategy of the Tourist Cluster Development in Smolensk Region for the Period of 2017 2020" was adopted to support the cluster. Starting from March 2019 the area has been referred to the Department of Investment Development of Smolensk Region to obtain visible economic results of the tourist development in the region[41].

It is worth mentioning that no other region of the Russian Federation is characterized by such a high territorial accessibility for the citizens of the Republic of Belarus, this facilitates border tourism and, long-term, international tourism. The above factors underlie the opportunity to develop in addition to the mass (culture-related) tourism such tourist areas as eco-tourism, primary wellness tourism, rural tourism, sports tourism, event tourism, faith tourism and pilgrim's journeys, archeological and industrial tourism. Recently tourists from Belorussia have preferred to combine cultural tourism in Smolensk region with business purposes, shopping and entertaining. Smolensk tourist agencies have one, two, three days' programs in place and thematic tours around Smolensk and the region. The project "Smolensk and Grand 
Nowadays due to the development of technologies and Duchy of Lithuania" and related have been developed to attract young people who had grown upon "the new Belorussian history". Also the branded tours "Romantic Appeal of the Manorial Estates on Smolensk Land", "Smolensk Natives in the Crimea History and Fate" have been invented[42].

Unique geographical features of Smolensk region (i.e. its near-capital position) determinate two more prospective ways of development - business tourism where business events are combined with quality excursion tours, and gastronomic tourism where traditional Smolensk cuisine is being promoted [24]. As is customary, at the weekends and at public holidays there are individual tourists from Moscow and Moscow region who arrive on cultural, educational and entertainment purposes. But the biggest mass target audience that is able to provide significant figures of the tourist flow is pupils coming from Moscow who are interested in various interactive programs and quests.

In this respect it becomes clear that there is a necessity of increasing the tourist attractiveness of the region through developing new thematic tours on various topics including the everlasting and timely theme "Smolensk Military Patriotic", also - "Vikings in Smolensk Land - Trade Route from the Varangians to the Greeks", "Tasty and Hearty Stories of Smolensk Land", etc.

Evidently there must be given support and assistance to the local producers of "regionally characteristic" products ("Smolensk flax", "Vyazma pryanik", "Smolensk beer", "Smolensk candies") that will result in their turn in the revival of the local industries and will contribute to the income of tax into the local budgets.

In terms of the limited budget financing and underinvestment we consider it urgent to develop and implement such technologies in the sphere of tourism that will be cost-effective and simultaneously facilitating public access to the information about the rich regional potential and sightseeing attractions.

Recent research of the tourist market demonstrates that there has been growth in the demand for active and nonstandard forms of tours and the key characteristics here is positive emotion and new experience combined with visiting many locations during a tour. Considering this direction of the market development we can expect increase in the demand for the so-called innovational tours aimed at tourists' active involvement into the process. It results in the appearance of new interactive ways to work with consumers of excursion tours.

One of innovations in tourism is introduction of interactive visualization of tours and excursions with the help of augmented VR that visualizes three-dimensional full-sized objects in real time and is applicable to the mass mobile devices.

Implementation of the augmented VR technique poses a problem that demands certain computer landscape for the input data processing, calculation of the 3D graphics and display representation. portable consumer electronic devices there have appeared meaningful factors to change the current situation.

By 2019 the augmented VR technologies have become part of everyday life of smart phone users and are offering a variety of diverse products to the consumers in the mobile market segment: entertaining, popular scientific and just helpful.

The opportunities of augmented VR in tourism are no fewer and perhaps even greater. Here are some possible examples:

1) Detailed description of any architecture object or other attraction. Anyone can point their smart-phones or tablet computers at an object and the special program recognizes it giving detailed description. In case with historical objects it is possible to demonstrate their original form or appearance after restoration and refurbishment.

2) Display of any location at a different time of the year. Using their personal gadgets anyone can see this or that place, location at a different period of a year.

In the neighboring regions the video-guide technology with the function of augmented VR is coming into use, on the basis of which anyone can obtain the necessary information about the object of interest, compare the time changing of objects, also - download the application to their mobile devices so that be able to turn to it anytime.

There are no alternatives to the above-mentioned software within our region. Among the products of similar character we can only draw your attention to the electronic guide for the Old Smolensk Road and the web-atlas "Smolensk Land in the War of 1812", a project of excursion taxi rotes.

The implementation of the augmented VR can result in the creation of a virtual tourist guide with the informative function based on the augmented VR and QR-code techniques to help provide developing modular tours. QR-code techniques are a cost-effective and technically easy form of information preservation. QR-codes on the walls of the buildings (that is widely used today in the Russian centers of mass tourism, far and near abroad), in information and advertising leaflets, on travel cards, tickets and souvenirs can cover the mass audience of the prospective customers.

The practical results of the introduction of the augmented VR technique into the touristic sphere lie in the independent and free character of such excursions and tours. IT technologies being added to excursions and educational tours allow to go sightseeing independently and get to know the touristic objects with the help of a mobile device only.

The practical meaning of the software is in the absence of a tour-guide who is substituted for a tourist's gadget providing all the information about the excursion tour including the sights and the supplementary infrastructure objects (food services areas, accommodation, transport, entertainment and leisure centers, etc).

The modular excursion tour can give a retrospective review of the object due to the augmented VR technique that 
At the same time augmented VR services have been enables to compare the building or monument's current appearance and the their old picture images and all this can be done only with the help of a smart phone or tablet PC where there has been installed special software.

This direction of the tour market development is in high demand today and very promising - it affords grounds for funding from both the local budgets and private capital as it enables high advertising prospects. Introduction of the visualization project of excursion tours will contribute to the growth of the tourist flow into Smolensk region, also - it will facilitate the navigation for tourists therefore providing both effective development of the tourism industry and traditional tours in the regional center adjacent to the main transport routes, and emerging of branded author tourism products including at the inter-municipal, interregional and international levels.

The practical relevance of the project consists in the possibility to directly apply the developed information software in the working business-centers of design and development, in the trade and some other areas.

Additionally the realization of the augmented VR project in the tourism industry will facilitate integration of the persons with limited and reduced mobility, i.e. of the category of consumers who currently have either limited access to the most part of the tourist products, or totally absent.

\section{CONCLUSION}

In conclusion we must underline that Smolensk region as investment has a number of advantages: favorable near-border position, natural resources potential, accumulated timehonored and human capital; in Russia the region is undoubtedly one of the most attractive for investment and it has potential.

Presently emphasized are such directions of regional development as hospitality industry (hotels, coffee shops, restaurants, museums, etc.) and regional logistic system (road and transport infrastructure).

Besides when it comes to investment, it turns out investors are not ready to co-finance the territory which is unknown to them in terms of its advantages and opportunities. The urgency of the well-formed presentation of the region is relevant as never before. The right presentation allows the region to attract and accumulate resources for its developing and this is possible thanks to the region's favorable brand image.

There may be relevant new ways of the region's presentation and positioning when the accumulated historical and symbolic capital and the local brands are taken into account.

Visualization as the augmented VR technique will allow to position the region efficiently not only in the near capital and near border segments but also in the remote areas.

We acknowledge the problems at the current stage of the realization of the above project on the augmented VR visualization of the excursion tours in the region, and these are issues of administrative and matching character. recently actively developing and seem to remain the key trend in the years to come, according to the industry analysts. The further development of such services depends directly on the marketing initiative of their developers in the field of electronic commerce and game industry as well as on the evolution of the mobile platforms.

The ways to make use of augmented VR are increasing in number with every passing year thanks to comprehensive, practical and friendly technologies that make the writing process of virtual application more simple and fast.

So, application of the augmented VR technologies in the tourism industry is considered most promising and attractive for investment owing to the available historical and cultural potential, geographic position of Smolensk region. Tourism development will contribute to the growth of the associated industries of the regional economy: road facilities, hospitality service, hospitality industry. All this will contribute to the region's favorable brand name, investment conditions and in the long run, to the economic recovery.

[1] D.P. Frolov, "Marketing regiona: diskussionnye voprosy metodologii i metodiki," Marketing v Rossii i za rubezhom, vol. 1(93), 2013, pp. 8390.

[2] H.D. Arslanova, "Investicionnye riski i puti ih preodolenija v problemnyh regionah (na primere regionov SKFO)," Regional'nye problemy preobrazovanija jekonomiki, vol. 6, 2017, pp. 52-58.

[3] I.S. Averina, M.E. Buyanova, "Improvement of the institutional model Encouragement of innovative activity as a condition of growth of competitive ability in the regional economy," Competitive, sustainable and secure development of the regional economy: response to global challenges Proceedings of the International Scientific Conference Editor Elena G. Russkova, Director, Institute of Economics and Finance, Volgograd State University, vol. 39, 2018, pp. 256-260.

[4] R.A. Bespalov, O.V. Bespalova, "Investicionnaja privlekatel'nost' Brjanskogo regiona v sovremennyh uslovijah," Regional'nye problemy preobrazovanija jekonomiki, vol. 11, 2015, pp. 112-116.

[5] T. Dyukina, V. Kordovitch, "Investment climate of the territory assessment problems," Competitive, sustainable and secure development of the regional economy: response to global challenges Proceedings of the International Scientific Conference Editor Elena G. Russkova, Director, Institute of Economics and Finance, Volgograd State University, vol. 39, 2018, pp. 606-611.

[6] S. Knyazev, "Application of dynamic capabilities of the economic system for the purposes of sustainable innovation development," Competitive, sustainable and secure development of the regional economy: response to global challenges Proceedings of the International Scientific Conference Editor Elena G. Russkova, Director, Institute of Economics and Finance, Volgograd State University, vol. 39, 2018, pp. 301-304.

[7] I.I. Kruzhkova, "Investicionnyj potencial Orlovskoj oblasti," vestnik sel'skogo razvitija i social'noj politiki, vol.3(7), 2015, pp. 33-37.

[8] C.M. Kuleshov, "Osobennosti innovacionno-investicionnogo klimata regionov Rossii," Internet-zhurnal «Naukovedenie», vol.1(1), 2014, [Jelektronnyj resurs]. - Rezhim dostupa: http:,"publ.naukovedenie.ru (data obrashhenija 20.11.2019).

[9] A.E. Lapin, V.A. Makeeva, "Rejtingovaja ocenka investicionnoj privlekatel'nosti regiona (na materialah ul'janovskoj oblasti)," Izvestija Saratovskogo un-ta, vol. 13(3-2), 2013, pp. 398-403.

[10] G. Merzlikina, E. Kuzmina, "Innovative Aspects of a Sustainable Regional Development," Competitive, sustainable and secure

\section{REFERENCES}


[23] L.Ju. Mazhar, S.A. Shherbakova, "Razvitie turizma v rossijskobelorusskom prigranich'e: prikladnye zadachi i nauchnyj poisk," Regional'nye issledovanija, vol. 1(51), 2016, pp. 168-172.

Propent of the regional economy: response to global challenges Russkova, Director, Institute of Economics and Finance, Volgograd State University, vol. 39, 2018, pp. 412-416.

[11] A.R. Nagimov, E.M. Akhmetshin, V.P. Slanov, R.N. Shpakova, M.P. Solomonov, D.P. Il'yaschenko, "Foresight Technologies in the Formation of a Sustainable Regional Development Strategy," European Research Studies Journal Volume XXI, vol. 2, 2018, pp. 741-752.

[12] E.V. Poltinina, "Imidzh $v$ sisteme faktorov, opredeljajushhih konkurentosposobnost' regiona," Social'no-jekonomicheskie javlenija i processy, vol. 4(062), 2014, pp. 77-82.

[13] Y. Saliko, N. Kuzmenko, "Formation and analysis of regional innovation landscape indicators," Competitive, sustainable and secure development of the regional economy: response to global challenges Proceedings of the International Scientific Conference Editor Elena G. Russkova, Director, Institute of Economics and Finance, Volgograd State University, vol. 39, 2018, pp. 135-140.

[14] S. Soboleva, "Cluster formation processes in innovative development of Russian regions," Competitive, sustainable and secure development of the regional economy: response to global challenges Proceedings of the International Scientific Conference Editor Elena G. Russkova, Director, Institute of Economics and Finance, Volgograd State University, vol. 39, 2018, pp. 453-455.

[15] V.Y. Sutyagin, Y.Y. Radyukova, "Public-private partnership as a necessity for sustainable investment development of the region," Competitive, sustainable and secure development of the regional economy: response to global challenges Proceedings of the International Scientific Conference Editor Elena G. Russkova, Director, Institute of Economics and Finance, Volgograd State University, vol. 39, 2018, pp. 443-448.

[16] V. Tikhiy, O. Koreva, "Innovative development of regions of Russia," Competitive, sustainable and secure development of the regional economy: response to global challenges Proceedings of the International Scientific Conference Editor Elena G. Russkova, Director, Institute of Economics and Finance, Volgograd State University, vol. 39, 2018, pp. 10-13.

[17] S.M. Vdovin, "Uluchshenie investicionnogo klimata kak predposylka ustojchivogo razvitija regiona," Regionologija, vol. 3, 2014, pp. 43-54.

[18] A.G. Zaytsev, M.A. Vlasova, "Cognitive approach to the analysis of innovative and investment potential of the region," Competitive, sustainable and secure development of the regional economy: response to global challenges Proceedings of the International Scientific Conference Editor Elena G. Russkova, Director, Institute of Economics and Finance, Volgograd State University, vol. 39, 2018, pp. 194-198.

[19] A. Volodchenkov, L. Zhebrunova, S. Shcherbakova, V. Mel'nikov, O. Kirsanova, K. Kupchenko, "Development of sustainable investment climate in the boundary region through implementation of the cluster mechanism (by the example of Smolensk region)," International Scientific-Practical Conference "Business Cooperation as a Resource of Sustainable Economic Development and Investment Attraction" (ISPCBC 2019). Part of series: Advances in Economics, Business and Management Research, 2019, pp. 529-533.

[20] A.P. Katrovskij, Ju.P. Kovalev, L. Mazhar, Ju.S. Shherbakova, "A.Turizm v prigranichny regionah teoreticheskie aspekty geograficheskogo izuchenija," Baltijskij region, vol. 9(1), 2017, pp. 113126.

[21] O.G. Kirsanova, S.A. Shherbakova, "Logisticheskij faktor razvitija turizma v Smolenskoj oblasti," Regional'nye issledovanija, vol. 4(50), 2015, pp. 132-137.

[22] L.Ju. Mazhar, S.A. Shherbakova, "Razvitie transgranichnogo turizma kak napravlenie modernizacii turistsko-rekreacionnoj dejatel'nosti v rossijsko-belorusskom prigranich'e," Regional'nye issledovanija, vol. 3(61), 2018, pp. 115-125.

[24] S.A. Shherbakova, "Proektirovanie turistskogo brenda (na primere goroda Smolenska)," Sovremennye problemy servisa i turizma, vol. 4, 2011, pp. 44-52.

[25] Handbook on Marketing Transnational Tourism Themes and Routes, World Tourism Organization (UNWTO) and European Travel Commission (ETC), 2017, pp.226.

[26] Y. Reisinger, International Tourism, 2010, pp.416.

[27] Tourism in Russia: A Management Handbook, 2015, pp.448.

[28] R. Virvilaité, R. Belousova, "Origin and Definition of Interactive Marketing," Engineering Economic, vol. 41(1), 2005, pp. 67-73.

[29] P.A. Pavlou, D.W. Stewart, "Measuring the Effects and Effectiveness of Interactive Advertising: A Research Agenda," Journal of Interactive Advertising, vol. 1(1), 2005, pp. 62-78.

[30] S.A. Shherbakova, "Formirovanie modeli turistskogo klastera Smolenskoj oblasti: jekonomiko-geograficheskij aspekt," Vestnik Moskovskogo gosudarstvennogo oblastnogo universiteta. Serija: Estestvennye nauki, vol. 1, 2018, pp. 77-85.

[31] S.A. Shherbakova, "Razvitie turizma v prigranichnyh oblastjah na osnove klasternogo podhoda (na primere Smolenskoj oblasti)," Vestnik Moskovskogo gosudarstvennogo oblastnogo universiteta. Serija: Estestvennye nauki, vol. 4, 2018, pp. 90-98.

[32] T.V. Kornienko, A.A. Potapov, "Ispol'zovanie dopolnennoj real'nosti v shkol'nom pechatnom izdanii," Kazanskij pedagogicheskij zhurnal, vol. 1, 2018, pp. 121-126.

[33] K.B. Kostin, "Forsajt razvitija tehnologij dopolnennoj real'nosti v mezhdunarodnom turizme," $\quad$ Izvestija Sankt-Peterburgskogo gosudarstvennogo jekonomicheskogo universiteta, vol. 6(102), 2016, pp. 57-63.

[34] K.B. Kostin, "Razvitie mezhdunarodnogo turizma posredstvom tehnologij dopolnennoj real'nosti," Problemy sovremennoj jekonomiki, vol. 1(65), 2018, pp. 174-177.

[35] A.T. Kozhombaeva, L.F. Mirgajazova, A.V. Shhetilov, "Povyshenie turisticheskogo potenciala posredstvom ispol'zovanija tehnologii dopolnennoj real'nosti: problemy i perspektivy," Reshetnevskie chtenija, 2016, pp. 210-212.

[36] L.G. Vihoreva, "Prilozhenija dopolnennoj real'nosti kak vspomogatel'nyj faktor rekreativnoj zhurnalistiki," Vestnik RUDN. Serija Literaturovedenie. Zhurnalistika, vol. 3, 2016, pp. 84-91.

[37] J. Larkin, "Marketing initiatives using QR codepp," Beverage Industry, vol. 9, 2010, p. 74.

[38] O.G. Kirsanova, "Perspektivy formirovanija zhivotnovodcheskogo klastera Smolenskoj oblasti," Social'no-jekonomicheskie problemy prodovol'stvennoj bezopasnosti: real'nost' i perspektiva. Materialy II Mezhdunarodnoj nauchno-prakticheskoj konferencii, 2017, pp. 86-91.

[39] O.G. Kirsanova, "Problemy razvitija dorozhnogo hozjajstva Smolenskoj oblasti v formirovanii regional'nogo logisticheskogo klastere," Potencial social'no-jekonomicheskogo razvitija Rossijskoj Federacii v novyh jekonomicheskih uslovijah. Materialy II mezhdunarodnoj nauchnoprakticheskoj konferencii v 2-h chastjah, 2016. pp. 279-283.

[40] O.G. Kirsanova, "Vnedrenie klasternogo podhoda v mehanizm povyshenija konkurentosposobnosti prigranichnogo regiona [Tekst]," Materialy VIII mezinarodni vedecko-practika konference, vol. 3, 2017, pp. 17-19.

[41] Oficial'nyj sajt Administracii Smolenskoj oblasti [Jelektronnyj resurs]. Rezhim dostupa: https:,"www.admin-smolensk.ru.

[42] S.A. Shherbakova, K.V. Kupchenko, "Obosnovanie turistskojekskursionnogo marshruta «Smoljane v sud'be i istorii Kryma»," Sovremennye problemy turizma i servisa, vol. 1, 2015, pp. 108-115. 